\title{
DPPH-Scavenging Activity of Propolis of Tetragonula iridipennis from East Kalimantan
}

\author{
Sukemi ${ }^{1}$ Yadi Yasir ${ }^{2}$ Swandari Paramita ${ }^{3}$ Enos Tangke Arung,"* \\ ${ }^{1}$ Chemistry Education Program Mulawarman University Samarinda, Indonesia \\ ${ }^{2}$ Faculty of Medicine Mulawarman University Samarinda, Indonesia \\ ${ }^{3}$ Research Center for Medicine and Cosmetics from Tropical Rainforest Resources Mulawarman University \\ Samarinda, Indonesia \\ ${ }^{4}$ Faculty of Forestry Mulawarman University Samarinda, East Kalimantan, Indonesia \\ *Corresponding author. Email: tangkearung@yahoo.com
}

\begin{abstract}
Tetragonula iridipennis is a species of bee from the Apidae family. Its honey is known as an anticancer by the local community in Samarinda, East Kalimantan, Indonesia. However, research on propolis of T. iridipennis from East Kalimantan is rarely conducted. This research was carried out to investigate the antioxidant activity of propolis of $T$. iridipennis. The propolis was collected from a villager at Lempake subdistrict, Samarinda city, East Kalimantan province, Indonesia. The antioxidant activity was evaluated using a 2,2-diphenyl-1-picrylhydrazyl (DPPH) radical scavenging assay, and ascorbic acid was taken as a standard. The propolis's DPPH scavenging activities were high but lower than ascorbic acid as a positive control. However, it can be concluded that the propolis of T. iridipennis from East Kalimantan can be used as an antioxidant agent
\end{abstract}

Keywords: Tetragonula iridipennis, Propolis, DPPH, Antioxidant

\section{INTRODUCTION}

Bee is an attractive insect and mostly visits flowers and participates in plant pollinations [1]. Indonesia has the most diverse honey bee species in the world [2]. Tetragonula iridipennis is a harmless bee called stingless bee that widely spread over the tropical and subtropical areas in the world [3]. A group of stingless bees produces propolis using their head gland, plant resins, and exudates, including inorganic and organic compounds. It uses the propolis as pillars, pots of honey, and other structures in their nests [3-4].

For a long time, propolis of stingless bees has been used as traditional medicine [3]. Some researchers reported that the propolis has antibacterial, antifungal, anti-inflammatory, antitumor, antioxidant activities [58]. Sources of floral and plant resins availability influence chemicals in propolis of stingless bee $[3,8]$. Chemical composition in samples influences their biological activities, and propolis of stingless bees from India have been reported to have antioxidant and antimicrobial activities [3].
However, research on T. iridipennis propolis from Samarinda city, East Kalimantan privince, Indonesia, has not been reported. This research was conducted to investigate the phytochemical and antioxidant activity of the propolis of $T$. iridipennis from Samarinda city $[5,6]$.

\section{MATERIAL AND METHODS}

\subsection{Sample and Chemicals}

Propolis of $T$. iridipennis was collected as a gift from a villager at Lempake subdistrict, Samarinda city, East Kalimantan province, Indonesia. The propolis was directly taken from the bee nest in January 2019. All the chemicals used in this research were analytical grade and purchased from Sigma Aldrich GmbH (Germany).

\subsection{Phytochemical Screening and Sample Fractionation}

The phytochemical screening tests were performed using the standard method described by Sukemi et al. 
[9]. The propolis of $T$. iridipennis was subjected to column chromatography over an open column of silica gel with the ratio of 1:25 (w/w) and then eluted with a gradient of solvents ( $n$-hexane - ethyl acetate methanol) to yield 29 fractions $\left(\mathrm{F}_{1}-\mathrm{F}_{29}\right)$.

\subsection{DPPH radical scavenging activity}

DPPH radical scavenging assay was conducted according to Sukemi et al. [9] with few modifications. A volume of $33 \mu \mathrm{l}$ of propolis of $T$. iridipennis and its fractions dissolved in ethanol was mixed with $467 \mu$ of ethanol and $500 \mu \mathrm{l}$ of $30 \mathrm{ppm}$ DPPH ethanolic solution. The mixture was left for 30 minutes. Then, the mixture absorbance was measured at $514 \mathrm{~nm}$ using UV-Vis spectrophotometer against a blank, and ascorbic acid was used as the control. The percentage of DPPH scavenging activity of the propolis was calculated as

$$
\text { Scavenging activity }=[(\mathrm{A} 0-\mathrm{A} 1) / \mathrm{A} 0)] \times 100 \%
$$

where A0 was the absorbance of DPPH without the propolis, A1 was the absorbance DPPH in the presence of the propolis.

Table 1. DPPH Radical Scavenging Activity of Propolis of T. iridipennis

\begin{tabular}{llc}
\hline \multicolumn{1}{c}{ Samples } & $\begin{array}{c}\text { Conc. } \\
(\mathbf{p p m})\end{array}$ & $\begin{array}{c}\text { Scavenging } \\
\text { activity } \\
(\boldsymbol{\%})\end{array}$ \\
\hline Ascorbic acid & 100 & $79.52 \pm 0.91$ \\
Propolis of $T$. iridipennis & 100 & $69.08 \pm 0.92$ \\
Fractionated propolis of $T$. iridipennis & 75 & \\
$\mathrm{~F}_{8}$ & & $84.17 \pm 0.30$ \\
$\mathrm{~F}_{9}$ & & $77.07 \pm 3.20$ \\
$\mathrm{~F}_{10}$ & $82.32 \pm 1.56$ \\
\hline
\end{tabular}

\section{RESULT AND DISCUSSIONS}

Propolis of the $T$. iridipennis contains alkaloid and phenolic compound groups. The most widely used method to evaluate the sample's capability as a donor of hydrogen to DPPH radicals is DPPH radical scavenging activity assay [10]. A stable product will be produced when DPPH radicals react with hydrogen donors [11]. DPPH-radical scavenging activities of the propolis, fractionated propolis $\left(\mathrm{F}_{5}-\mathrm{F}_{10}\right)$, and ascorbic acid is shown in table 1 . As seen in Table 1 , it is clear that the DPPH radical scavenging activity of $100 \mathrm{ppm}$ of propolis of $T$. iridipennis was $69.08 \%$ and was lower than that of $100 \mathrm{ppm}$ of ascorbic acid (79.52\%), respectively. However, three fractionated propolis $\left(\mathrm{F}_{8^{-}}\right.$ $\left.\mathrm{F}_{10} ; 75 \mathrm{ppm}\right)$ were much higher in their scavenging activity than the $100 \mathrm{ppm}$ of ascorbic acid. The most increased DPPH radical scavenging activity was $\mathrm{F}_{8}$ $(84.12 \%)$, followed by $F_{10}(82.32 \%)$ and $F_{9}(77.07 \%)$. The antioxidant activity of the propolis of $T$. iridipennis and its fractions might cause by their secondary metabolites, such as phenolic compound groups. The presence of phenolic compound groups in a plant's extracts is associated with their DPPH radical scavenging activity [12]. Phenolic compounds can neutralize DPPH radicals by donating their proton [13].

\section{CONCLUSIONS}

Antioxidant activity of propolis of T. iridipennis and its fractions to scavenge DPPH-radicals have been conducted. The propolis and its fractions $\left(\mathrm{F}_{8}-\mathrm{F}_{10}\right)$ can be used as sources of an antioxidant agent.

\section{ACKNOWLEDGMENTS}

The authors thank the ministry of research, technology, and higher education of the Indonesian Republic for funding this research.

\section{REFERENCES}

[1] C. Rasmussen, J.C. Thomas, M.S. Engel, New genus of eastern hemisphere stingless bees (Hymenoptera: Apidae), with a key to the supraspecific groups of Indomalayan and Australasian meliponini, American Museum Novitates, 2017, pp. 1-37.

[2] S. Hadisoesiloe, The diversity of indigenous honey bee species of Indonesia, Biodiversitas, 2, 2001, pp. 123-128.

[3] D.M. Kasote, M.V. Pawara, S.S. Gundub, R. Bhatiab, V.S. Nandreb, S.D. Jagtapa, S.G. Mahajanb, M.V. Kulkarni, Chemical profiling, antioxidant, and antimicrobial activities of Indian stingless bees propolis samples, Journal of Apicultural Research, 58, 2019, pp. 617-625.

[4] A.M. Stearman, E. Stierlin, M.E. Sigman, D.W. Roubik, D. Dorrien, Stradivarius in the jungle: Traditional knowledge and the use of "black beeswax" among the Yuqui of the Bolivian Amazon, Human Ecology, 36, 2008, pp. 149-159.

[5] J.F. Campos, U.P. dos Santos, L.F.B. Macorini, A.M.M.F. de Melo, J.B.P. Balestieri, E.J. ParedesGamero, E.L. dos Santos, Antimicrobial, antioxidant and cytotoxic activities of propolis from Melipona orbignyi (Hymenoptera, Apidae), Food and Chemical Toxicology, 65, 2014, pp. 374-380.

[6] M.K. Choudhari, R. Haghniaz, J.M. Rajwade, and K.M. Paknikar, Anticancer activity of Indian stingless bee propolis: An in vitro study, Evidencebased complementary and alternative medicine, 2013.

[7] S. Kothai, B. Jayanthi, Anticancer activity of silver nanoparticles biosynthesized using stingless bee propolis (Tetragonula iridipennis) of Tamil Nadu, 
Asian Journal of Biomedical and Pharmaceutical Sciences, 5, 2015, pp. 1-30.

[8] F.C. Massaro, P.R. Brooks, H.M. Wallace, F.D. Russell, Cerumen of Australian stingless bees (Tetragonula carbonaria): Gas chromatographymass spectrometry fingerprints and potential antiinflammatory properties, Naturwissenschaften, 98, 2011, pp. 329-337.

[9] Sukemi, K. Khownium, E.T. Arung, I.W. Kusuma, W. Mingvanish, Antioxidant Activities of crude methanolic extract of Nephelium ramboutanake (Labill.) Leenh. peel, Proceeding Pure and Applied Chemistry International Conference 2015 (PACCON2015), 2015, 123-127.

[10] B. Hsu, I.M. Coupar, K. Ng, Antioxidant activity of hot water extract from the fruit of the doum palm, Hyphaene thebaica, Food Chemistry, 98, 2006, pp. 317-328.

[11] E. Bendary, R.R. Francis, H.M.G. Ali, M.I. Sarwat, S.E. Hady, "Antioxidant and structureactivity relationships (SARS) of some phenolic and anilines compounds," Annals of Agricultural Sciences, 58, 2013, pp. 173-181.

[12] S. Dudonné, X. Vitrac, P. Coutière, M. Woillez, J. Mérillon, Comparative study of antioxidant properties and total phenolic content of 30 plant extracts of industrial interest using DPPH, ABTS, FRAP, SOD, and ORAC assays, Journal Agricultural and Food Chemistry, 57, 2009, pp. 1768-1774.

[13] A.A. Al-Amiery, A.A.H. Kadhum, H.R. Obayes, and A.B. Mohamad, Synthesis and antioxidant activities of novel 5-chlorocurcumin, complemented by semiempirical calculations, Bioinorganic Chemistry and Applications, 2013, pp. 1-7. 